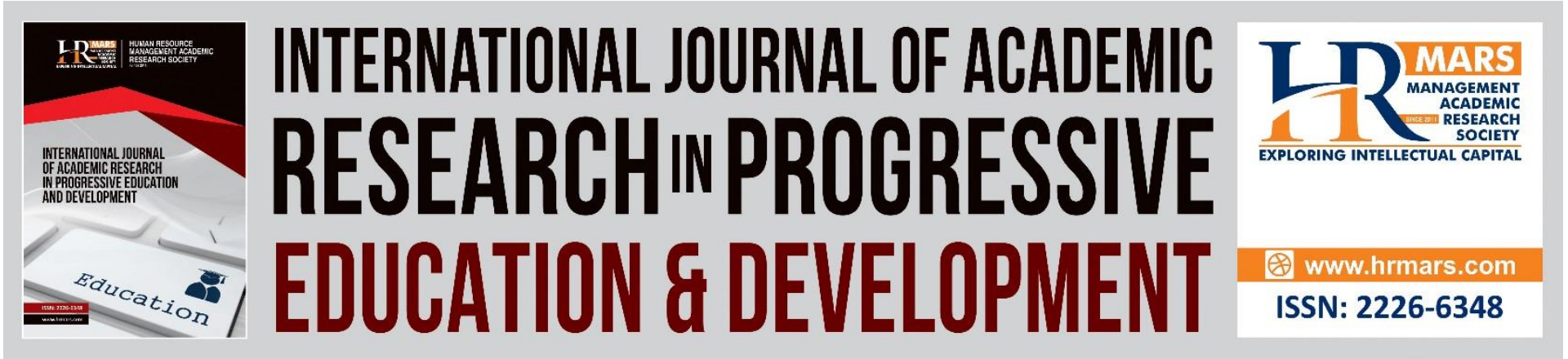

\title{
Creativity Practice in Teaching and Facilitating (PDPC) Malaysia's PVMA Automotive Due Covid-19 Pandemic
}

\author{
Mohd Najib Ab Kadir, Sarimah Ismail
}

To Link this Article: http://dx.doi.org/10.6007/IJARPED/v10-i3/10699

DOI:10.6007/IJARPED/v10-i3/10699

Received: 05 June 2021, Revised: 08 July 2021, Accepted: 27 July 2021

Published Online: 20 August 2021

In-Text Citation: (Kadir \& Ismail, 2021)

To Cite this Article: Kadir, M. N. A., \& Ismail, S. (2021). Creativity Practice in Teaching and Facilitating (PDPC) Malaysia's PVMA Automotive Due Covid-19 Pandemic. International Journal of Academic Research in Progressive Education and Development, 10(3), 396-411.

Copyright: (C) 2021 The Author(s)

Published by Human Resource Management Academic Research Society (www.hrmars.com)

This article is published under the Creative Commons Attribution (CC BY 4.0) license. Anyone may reproduce, distribute, translate and create derivative works of this article (for both commercial and non-commercial purposes), subject to full attribution to the original publication and authors. The full terms of this license may be seen

at: http://creativecommons.org/licences/by/4.0/legalcode

Vol. 10(3) 2021, Pg. 396 - 411

http://hrmars.com/index.php/pages/detail/IJARPED

JOURNAL HOMEPAGE

Full Terms \& Conditions of access and use can be found at http://hrmars.com/index.php/pages/detail/publication-ethics 


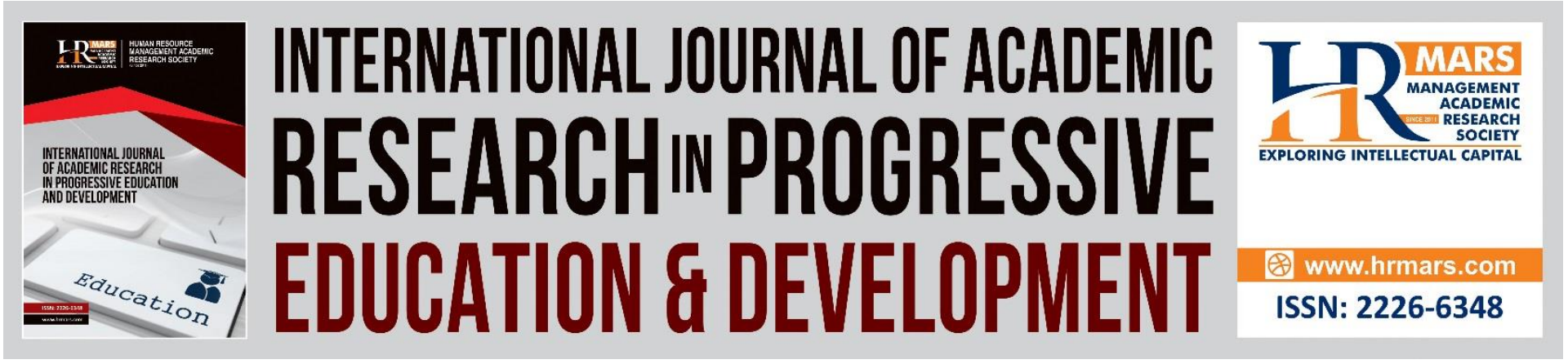

\title{
Creativity Practice in Teaching and Facilitating (PDPC) Malaysia's PVMA Automotive Due Covid- 19 Pandemic
}

\author{
Mohd Najib Ab Kadir, Sarimah Ismail \\ School of Education, Faculty of Social Sciences and Humanities, Universiti Teknologi \\ Malaysia, 81310 Skudai, Johor, Malaysia \\ Email: ajib8022@gmail.com
}

\begin{abstract}
The need for instructors who are creative in conducting PVMA automotive teaching process is a key requirement in this study. The world was taken aback with the Covid-19 outbreak and Malaysia recorded its first case back in January 2020. The outbreak forced all educational institutions to be closed immediate, making it hard for instructors to carry out a physical learning session. This posed as a challenge to teachers and creative teaching is seen to be a great solution especially in the PVMA (automotive) field by diversifying teaching techniques in the previous teaching and facilitation $(\mathrm{PdPc})$ to the current situation by adopting blended learning via online and face-to-face interaction. Therefore, a qualitative study was conduction to collect data on creative teaching. Data were obtained through interviews submitted to experts answer the research questions and reached data saturation point by the fifth expert. Interview transcripts were analyzed using NVivo software and the open coding showed the teacher's creativity level is very high in helping students to master their learning especially in the PVMA automotive. There are five constructs found from the interview analysis namely PdPc techniques, teacher personality, knowledge, environment, motivation and thinking skills. That construct is aligned with the six elements of creativity in Stenberg's creative teaching theory namely environment, motivation, knowledge, intelligence, personality and thinking style. Therefore, this study suggests that training and experience can help teachers to develop creativity in PdPc process. The training received by the instructors should cover the latest technology used in the industry to apply the skills and knowledge to students during the teaching and facilitation process.
\end{abstract}

Keywords: Techniques Vocational, Creativity, Teaching and Learning Process

\section{Introduction}

When the Ministry of Health Malaysia confirmed the spread of Covid-19 in the country through a press conference on January 27, 2020, the government has since taken many unprecedented measures in curbing the spread of the deadly disease in the community. One of them is implementing the Movement Control Order (MCO) nationwide starting $18^{\text {th }}$ March 2020 (Salim et al., 2020). Similar measure was also enforced in the other 160 countries 
worldwide $($ UNESCO,2020) in order to control the spread of the novel coronavirus (Alsafi et al., 2020). Consequently, this extreme measure has given an impact to many sectors such as economy, social, tourism, transportation and not to forget, education. When the daily cases statistics did not improve after 18 months, the government, once again, come up with another proactive measure by introducing the National Vaccination program which aimed to form herd immunity by vaccinating $70 \%$ of Malaysia's population by the end of 2021 (Khairy, 2021). There are numerous measures taken by the government during MCO period which has given a huge impact to the educational institution. Malaysia's educational system has gone through a lot of changes including a prolonged closure of primary and secondary school since March 2020 till May 2021. These changes leave a serious impact towards students' learning.

Nevertheless, learning should be continued to make sure students are not left behind. It is also a continuous effort to expand an individual's potential (Asnul et. al., 2013). Therefore, when the Ministry of Education announced the implementation of online learning, many agreed with the idea. It was widely implemented throughout the whole educational institutions in the country with a few adjustments considering the students' level, background, and a few other aspects to ensure a successful implementation of online teaching. Teachers need to attract students' interest to participate in online classes by being creative in using technological aids.

Online learning presents many challenges for students in the Vocational Education and Training especially the Upper Secondary Vocational educational in automotive (PVMA). The PVMA (automotive) students are the Form 4 and Form 5 students who are following the Malaysia Skill Certificate (SKM) Level 2 whom typically benefit from practical learning. However, since the implementation of remote learning, teachers have to be creative in giving the best education that they can to these students via online approaches.

The aim of teaching and learning process done by teachers is to deliver knowledge to students. As defined by (Reilly et al., 2011). teaching is viewed as creative when a teacher successfully combines their existing knowledge in a new or unique way to encourage cognitive processes that can produce desirable outcome. Building a unique and meaningful knowledge is also deemed as a creative way of teaching (Rinkevich, 2011). An effective teaching is done through many ways and the innovation of teaching method is what drives a teacher's creativity.

The Malaysia National Educational Philosophy (NEP) also highlights the production of creative individuals. Hence, the teachers should play the main role model in modelling creativity through their teaching and learning session. Barron dan Harrington (1981), emphasized that exploring different ways to approach a practical problem without following the standard operating procedures illustrates the perfect creativity. Teachers and students who are able to complete a task without being bound by the standard procedures can be considered creative (Adiguzel \& Cardak, 2009). Additionally, teacher's interest in technological tools could help them to deliver an effective teaching (Mishra dan Mehta 2017). According to Mehta et al. (2019), the need in technological usage could help to enhance students' understanding apart from helping the teachers to master their technological skills. The lack in technological support may block a teacher's creativity in teaching nonetheless, the teaching and learning process of the students must continue on.

Thus, this qualitative research is conducted to identify the creative elements as well as methods used by PVMA (automotive) teachers. This research is hoped to serve as a guide 
especially for other PVMA teachers and also teachers in the vocational and training field to provide a quality teaching and learning session as encouraged by the MOE.

\section{Problem Statement}

Based on the initial research conducted, it was found that inadequate technological equipment and materials, lack of experience in online teaching, students' lack of online learning tools, students' lack of learning tools to conduct practical learning at home and internet accessibility are the challenges faced by PVMA (automotive) teachers to conduct online learning. These challenges block teacher's creativity as suggested Sternberg (2006) that the environment, motivation, knowledge, intelligence, personality and thinking skills were not applied in the problems found in the initial research. Nonetheless, the teaching and learning of this PVMA (automotive) need to resume under any circumstances as to ensure that students will continue to learn. This research aims to find out the elements of creativity and methods used by PVMA (automotive) teachers.

\section{Research Objective}

a) To explore the creativie elements in the teaching process of PVMA (automotive) teachers.

b) To identify the teaching methods used by PVMA (automotive) teachers during the teaching and learning session.

\section{Research Questions}

a) What are the elements of creativity used by the PVMA (automotive) teachers?

b) What are the creative methods used by PVMA (automotive) teachers during the teaching and learning session?

\section{Literature review}

Motivation is associated with the inner drive of an individual to achieve their own potential. The interaction between a student and teacher through various approaches is a meaningful motivation for the learning process (Duta et al., 2015). Hence, when there are environmental challenges, teachers will find an alternative to give the best education to their students. A study has found out that there's a positive and significant correlation between motivation and students' academic outcome (Singer and Robert, 1980).

It is the nature of an educator to have a strong motivation that drive them to problem solving. Tasrim dan Elihami (2020) states that motivation is the urge that fuel an individual to complete their task consistently. This aligns with one of the creativity elements suggested by Stenberg (2006) which is motivation. With motivation, teachers or educators become creative in their profession to give a quality education to the students.

The pandemic has forced the educational institutions to take a drastic measure in order to resume with teaching and learning session by empowering online learning to ensure that no students are not left behind in their education. Teachers' determination and creativity can be seen in their effort to diversify online learning for students' comprehension and to achieve the objectives of their lesson.

Overall, online teaching and learning method is conducted with a variety of approaches catering to the lesson and a teacher's creativity. The student's level, either primary, secondary or university level, is also taken into account when designing a lesson. Generally, online teaching and learning for secondary level is a new concept or approach with 
many challenges presented especially limited internet accessibility and lack of learning tools such as laptop or computer. According to Hibbi et al., (2020). the common problems faced by students in online learning is the lack of learning tools such as laptop, smartphone and internet-based applications. Other challenges include internet connection problem due to high traffic or limited internet data (Kumar et al., 2020). Geographical factor is also a challenge for a stable internet connection.

Chin (2020), pointed out that the primary and secondary education in Malaysia is still practicing face-to-face learning. In order to keep up with the lesson, online learning is considered the safest option available on top of using other alternatives; depending on a teacher's creativity, as teaching method amidst the pandemic. Virtual learning has been widely accepted as a new shift in Malaysia's educational system since the implementation of MCO by the government was announced (KPM, 2020). As an effort to help teachers to adjust to this new online dynamic and helping students to optimize their learning, a guideline and manual of online teaching and learning session have been released through a circular dated $27^{\text {th }}$ March 2020 and $2^{\text {nd }}$ February 2020 respectively (Abd Latip,2020). All responsible parties namely the Ministry of Education (MOE), the State Education Department, the District Education office, schools, teachers, guardians and the community should support this new change to ensure the success of online teaching and learning session.

MOE has shown a high commitment to ensure the continual of learning for students in the technical education by providing a detailed guideline for the teaching and learning session. However, providing a full learning experience on practical knowledge via online is a challenge for educators due to the lack of learning materials and tools.

Online learning medium is used by all educators worldwide during this pandemic. Some popular platforms include Zoom, GoToMeeting, GoToWebinar, Google Meet, Cisco Webex. Chat applications such as WhatsApp and Telegram, video, YouTube and video-chat based applications such as Skype zoom were also widely used as it offers two-way communications. A teaching video can be utilized as additional tools in attracting students' attention and improving their learning performance (Wortlitz et al., 2016).

Creativity theory put forward by Stenberg has elements that is alligned with the creativity aspect of the research. According to Mohamad Sattar et. al., (2013), Sternberg's element of creativity allows an individual to develop their skills through a creative way while giving meaning towards their research. This theory is a fundamental element that is emphasized by the MOE in the area of creative and critical thinking. Apart from that, based on the analysis done, this theory is used in many researches that are related to creativity. The theory proposed different but interrelated resources in creativity namely intellectual abilities, knowledge, styles of thinking, personality, motivation, and environment.

Creativity stimulation refers to the reason that drive PVMA teachers' behaviour to encourage students' creativity while creative teaching refers to the social role played by the PVMA teachers in online classes such as guiding, training and teaching based on their knowledge, skills and the objective that they want to achieve. The creativity stimulation and creative teaching is needed as the variables in this research. The knowledge and skills in content, pedagogical organization and communications aspect need to be explain in great length when PVMA teachers conduct their creative teaching and learning session via online (Syed et al., 2021). Table 1 shows meta analysis from Scopus articles that discuss the teaching methods used during MCO. In total, there are 32 articles discuss about creativity learning dan 
INTERNATIONAL JOURNAL OF ACADEMIC RESEARCH IN PROGRESSIVE EDUCATION AND

DEVELOPMENT

Vol. 10, No. 3, 2021, E-ISSN: 2226-6348 @ 2021 HRMARS

teaching from January 2020 until Mei 2021 but only 11 of them fit the current research in table 2.1

Tabel 2.1: Meta analysis article fom Scopus

\begin{tabular}{|c|c|c|c|c|}
\hline Title & Year & $\begin{array}{l}\text { Publishe } \\
r\end{array}$ & Learning Proses & Autor \\
\hline $\begin{array}{l}\text { Responding to } \\
\text { COVID-19 and } \\
\text { transitioning to } \\
\text { online } \\
\text { learning:Evaluation } \\
\text { of an institution wide } \\
\text { capacity building } \\
\text { efforts on } \\
\text { technology- } \\
\text { enhanced learning }\end{array}$ & 2021 & $\begin{array}{l}\text { Rajaram } \\
\text { bapu } \\
\text { Institute } \\
\text { Of } \\
\text { Technolo } \\
\text { gy }\end{array}$ & $\begin{array}{l}\text { Platforms for online } \\
\text { video conferencing and } \\
\text { classroom teaching } \\
\text { through platforms such } \\
\text { as Zoomand CANVAS, } \\
\text { GoogleMeet, and WebEx. }\end{array}$ & $\begin{array}{l}\text { Syed K., Kandakatla } \\
\text { R., } \\
\text { Madhulita,Yadav } \\
\text { R., Himasagarika R. }\end{array}$ \\
\hline $\begin{array}{l}\text { Implementation of } \\
\text { ICAP principles } \\
\text { through technology } \\
\text { tools: Exploring the } \\
\text { alignment between } \\
\text { pedagogy and } \\
\text { technology }\end{array}$ & 2021 & $\begin{array}{l}\text { Rajaram } \\
\text { bapu } \\
\text { Institute } \\
\text { Of } \\
\text { Technolo } \\
\text { gy }\end{array}$ & $\begin{array}{l}\text { Conduct online lectures } \\
\text { interactively, students } \\
\text { are asked to copy notes, } \\
\text { question and answer } \\
\text { sessions, group } \\
\text { discussions so that } \\
\text { learning takes place in } \\
\text { two ways example use } \\
\text { window, slide } \\
\text { presentation }\end{array}$ & $\begin{array}{lr}\text { Deepika } & \text { A., } \\
\text { Kandakatla } & \text { R., } \\
\text { Saida A., Reddy V.B. }\end{array}$ \\
\hline $\begin{array}{l}\text { COVID-19 impact on } \\
\text { undergraduate } \\
\text { teaching: } \quad \text { Medical } \\
\text { radiation } \quad \text { science } \\
\text { teaching } \quad \text { team } \\
\text { experience }\end{array}$ & 020 & $\begin{array}{l}\text { Elsevier } \\
\text { Inc. }\end{array}$ & $\begin{array}{l}\text { Impact on teaching staff } \\
\text { where face -to -face } \\
\text { teaching is replaced by } \\
\text { online learning }\end{array}$ & $\begin{array}{l}\text { Currie G., Hewis J., } \\
\text { Nelson T., Chandler } \\
\text { A., Nabasenja C., } \\
\text { Spuur K., Barry K., } \\
\text { Frame N., Kilgour A. }\end{array}$ \\
\hline $\begin{array}{l}\text { Challenges, } \\
\text { collaboration, and } \\
\text { innovation in } \\
\text { rheumatology } \\
\text { education during the } \\
\text { COVID-19 pandemic: } \\
\text { leveraging new ways } \\
\text { to teach }\end{array}$ & 020 & $\begin{array}{l}\text { Springer } \\
\text { Science } \\
\text { and } \\
\text { Business } \\
\text { Media } \\
\text { Deutschl } \\
\text { and } \\
\text { GmbH }\end{array}$ & $\begin{array}{l}\text { ViRL Collaborative with } \\
\text { expert speakers invited } \\
\text { by the program director } \\
\text { of this institution to give } \\
\text { online talks } \\
\text { simultaneously }\end{array}$ & $\begin{array}{l}\text { Dua A.B., Kilian A., } \\
\text { Grainger R., Fantus } \\
\text { S.A., Wallace Z.S., } \\
\text { Buttgereit F.,Jonas } \\
\text { B.L. }\end{array}$ \\
\hline $\begin{array}{lr}\text { Learning dialogues } \\
\text { orchestrated with } \\
\text { BookRoll: A case } \\
\text { study } & \text { of } \\
\text { undergraduate } & \end{array}$ & 2020 & $\begin{array}{l}\text { Asia- } \\
\text { Pacific } \\
\text { Society } \\
\text { for } \\
\text { Compute } \\
\text { rs in }\end{array}$ & $\begin{array}{l}\text { Online learning, Learning } \\
\text { Dialogue (LeD), such as } \\
\text { the BookRoll eBook, } \\
\text { along with conferencing } \\
\text { support tools such as } \\
\text { video }\end{array}$ & $\begin{array}{l}\text { Kannan } \\
\text { Warriem } \\
\text { Majumdar R., } \\
\text { Ogata H. }\end{array}$ \\
\hline
\end{tabular}




\begin{tabular}{|c|c|c|c|c|}
\hline $\begin{array}{l}\text { physics class during } \\
\text { COVID-19 lockdown }\end{array}$ & & $\begin{array}{l}\text { Educatio } \\
\mathrm{n}\end{array}$ & & \\
\hline $\begin{array}{l}\text { From blended } \\
\text { teaching to online } \\
\text { teaching in the days } \\
\text { of Covid19. Student } \\
\text { visions }\end{array}$ & 2020 & $\begin{array}{l}\text { Red } \\
\text { Universit } \\
\text { aria de } \\
\text { Campus } \\
\text { Virtuales }\end{array}$ & $\begin{array}{l}\text { Online learning by } \\
\text { diversifying methods, } \\
\text { video, live chat, } \\
\text { presentation slides by } \\
\text { practicing blended } \\
\text { teaching }\end{array}$ & $\begin{array}{l}\text { Area-Moreira M., } \\
\text { bethencourt- } \\
\text { Aguilar A., Martín- } \\
\text { Gómez S. }\end{array}$ \\
\hline $\begin{array}{l}\text { Digital } \\
\text { Transformation in } \\
\text { Academic Society } \\
\text { and Innovative } \\
\text { Ecosystems in the } \\
\text { World beyond } \\
\text { Covid19-Pandemic } \\
\text { with Using 7PS } \\
\text { Model for loT }\end{array}$ & 2020 & $\begin{array}{l}\text { Institute } \\
\text { of } \\
\text { Electrical } \\
\text { and } \\
\text { Electroni } \\
\text { cs } \\
\text { Engineer } \\
\text { s Inc. }\end{array}$ & $\begin{array}{l}\text { Video apps like Zoom and } \\
\text { Adober Connect, } \\
\text { messenger apps like } \\
\text { WhatsApp and Telegram, } \\
\text { video, YouTube, and } \\
\text { video chat apps like } \\
\text { Skyper zoom } \\
\text { sustainability with } \\
\text { environmental, } \\
\text { economic, social, } \\
\text { educational, cultural, } \\
\text { technical, and political } \\
\text { aspects }\end{array}$ & $\begin{array}{l}\text { Mohammadian } \\
\text { H.D., Shahhoseini } \\
\text { H., Castro M., Merk } \\
\text { R. }\end{array}$ \\
\hline $\begin{array}{l}\text { Webinars: An } \\
\text { assistive tool used by } \\
\text { higher education } \\
\text { educators during } \\
\text { Covid19 case study }\end{array}$ & 2020 & $\begin{array}{l}\text { Institute } \\
\text { of } \\
\text { Electrical } \\
\text { and } \\
\text { Electroni } \\
\text { cs } \\
\text { Engineer } \\
\text { s Inc }\end{array}$ & $\begin{array}{l}\text { Webinars are live } \\
\text { lectures broadcast } \\
\text { through the internet } \\
\text { Zoom/ GoToMeeting, } \\
\text { GoToWebinar, Google } \\
\text { Meet, Cisco Webex }\end{array}$ & $\begin{array}{l}\text { Kumar } \\
\text { Malhotra A., } \\
\text { KatochA,Sarathkar } \\
\text { A., Manocha A. }\end{array}$ \\
\hline $\begin{array}{l}\text { Paradigm Shift in } \\
\text { Engineering } \\
\text { Education during } \\
\text { COVID-19: From } \\
\text { Chalkboards to Talk } \\
\text { Boards }\end{array}$ & 2020 & $\begin{array}{l}\text { Institute } \\
\text { of } \\
\text { Electrical } \\
\text { and } \\
\text { Electroni } \\
\text { cs } \\
\text { Engineer } \\
\text { s Inc. }\end{array}$ & $\begin{array}{l}\text { Webinar or online } \\
\text { through } 6 \text { strategies (i) } \\
\text { pedagogical and } \\
\text { instructional strategies; } \\
\text { (ii) content; (iii) } \\
\text { presentation style; (iv) } \\
\text { platform; (v) ethics, and } \\
\text { (vi) evaluation }\end{array}$ & $\begin{array}{l}\text { Malhotra S., Dutta } \\
\text { R., Amit Kumar, } \\
\text { Sagar Mahna D }\end{array}$ \\
\hline $\begin{array}{lr}\text { COVID-19 } & \text { and } \\
\text { education system: } \\
\text { Impact of current } \\
\text { pandemic } \\
\text { adaptive learning } \\
\text { strategies in medical } \\
\text { education system } \\
\end{array}$ & 2020 & $\begin{array}{l}\text { J. K. } \\
\text { Welfare } \\
\text { and } \\
\text { Pharmas } \\
\text { cope } \\
\text { Foundati } \\
\text { on } \\
\end{array}$ & $\begin{array}{l}\text { Forms of digital platforms } \\
\text { (websites and } \\
\text { conversational media) E- } \\
\text { learning }\end{array}$ & $\begin{array}{lll}\text { Patil } & \text { D., } & \text { Naqvi } \\
\text { W.M. } & & \end{array}$ \\
\hline $\begin{array}{l}\text { Online education } \\
\text { during the COVID19 }\end{array}$ & 2020 & $\begin{array}{l}\text { Academi } \\
\text { c }\end{array}$ & $\begin{array}{l}\text { Microsoft Teams, Google } \\
\text { Classroom or Zoom or by }\end{array}$ & $\begin{array}{l}\text { Maier V., Alexa L., } \\
\text { Craciunescu R. }\end{array}$ \\
\hline
\end{tabular}


DEVELOPMENT

Vol. 10, No. 3, 2021, E-ISSN: 2226-6348 @ 2021 HRMARS

\begin{tabular}{|c|c|c|c|c|}
\hline $\begin{array}{l}\text { pandemic: } \\
\text { Perceptions and } \\
\text { expectations of } \\
\text { romanian students }\end{array}$ & & $\begin{array}{l}\text { Conferen } \\
\text { ces and } \\
\text { Publishin } \\
\text { g } \\
\text { Internati } \\
\text { onal } \\
\text { Limited }\end{array}$ & $\begin{array}{l}\text { using their internal } \\
\text { Learning Management } \\
\text { System in Moodle or } \\
\text { Blackboard }\end{array}$ & \\
\hline $\begin{array}{l}\text { The } \\
\text { Digital/Technological } \\
\text { Connection with } \\
\text { COVID-19: An } \\
\text { Unprecedented } \\
\text { Challenge in } \\
\text { University Teaching }\end{array}$ & 2020 & Springer & $\begin{array}{l}\text { Technology Teaching } \\
\text { tools (online learning) + } \\
\text { Creativity + Access model }\end{array}$ & $\begin{array}{l}\text { Nuere S., de Miguel } \\
\text { L. }\end{array}$ \\
\hline
\end{tabular}

Lectures were done online using the internet as a medium of connectivity (Currie, et al., 2020). However, two-way interactive communications were stressed when learning such as copying lecture notes, questions and answer session and group discussion and these were done through application such as Google Meet, WebEx with window user support as well as slides presentation (Deepika et al., 2021). In addition to these applications, Microsoft Teams, Google Classroom or Zoom or using the internal operating system of the institution in Moodle or Blackboard were also used (Maier et al., 2020). Patil and Naqvi (2020) suggests that elearning should be done through the digital platform like websites and media communication. A study done by (Syed et al., 2021) on the perception of online teaching and learning with the online evaluation found that conference like platform and e-teaching using video showed the highest usage among students. This learning could enhance related learning behavior apart from giving the inspiration to the teachers to share their ideas and expertise through the video created (Area-Moreira et al., 2020; Mohammadian et al., 2020). Kannan et al., (2020) suggest that Online learning, Learning Dialogue (LeD), like eBook Book Roll together with supporting material of conference-like video is really helpful in the teaching and learning process of the students.

In addition to that, Nuere \& Miguel (2020), in his study found that online learning could be done through various medium such as making video, using apt study model, direct communication, power point presentation and this depends on the creativity of the teacher in grabbing the students' attention. Teacher or educator knows how to adopt and adapt in order to ensure the effectiveness of their teaching. Kumar et al. (2020), suggested 6 online teaching strategy that could give a good impact in the learning process namely (i) pedagogy and instructional, (ii) content, (iii) delivery (iv) platform, (v) ethics and lastly (vi) evaluation.

An article by Dua et al. (2020) stated that ViRL Collaborative program founded by a team of program director from varying institutions has given an impactful effect to the students. Experts from these institutions were called on to share their knowledge through online platform all at the same time. Despite these minor challenges that posed some difficulties in online learning, traditional method of learning was used in the teaching and learning process to help the students to get equality in education. One of the initiatives used was the preparation of learning module by the school or respective educational institutions. 
DEVELOPMENT

Vol. 10, No. 3, 2021, E-ISSN: 2226-6348 @ 2021 HRMARS

\section{Methodology}

This section emphasized on the research design, research process, research population, research sample, research sample size, sampling method, research instruments, research validity, pilot study, item reliability, data collection method dan analysis method. Cohen (2007); Creswell (2014) assert that an accurate research methodology can illustrate accurate findings and help to achieve the research objectives.

\section{Research Design}

Research design help to collect accurate data that can answer the research questions and achieve the research objectives at the same time (Linacre, 2005). Kaplan (2005), pointed out that the ability to obtain accurate information that can answer the research questions depends on the research design. There are 3 research designs outlined namely quantitative research, qualitative research and mixed-method research (Creswell and Clark, 2007). This study employs the qualitative research method.

\section{Research Process}

The research process involves the following (as shown in Figure 3.2):

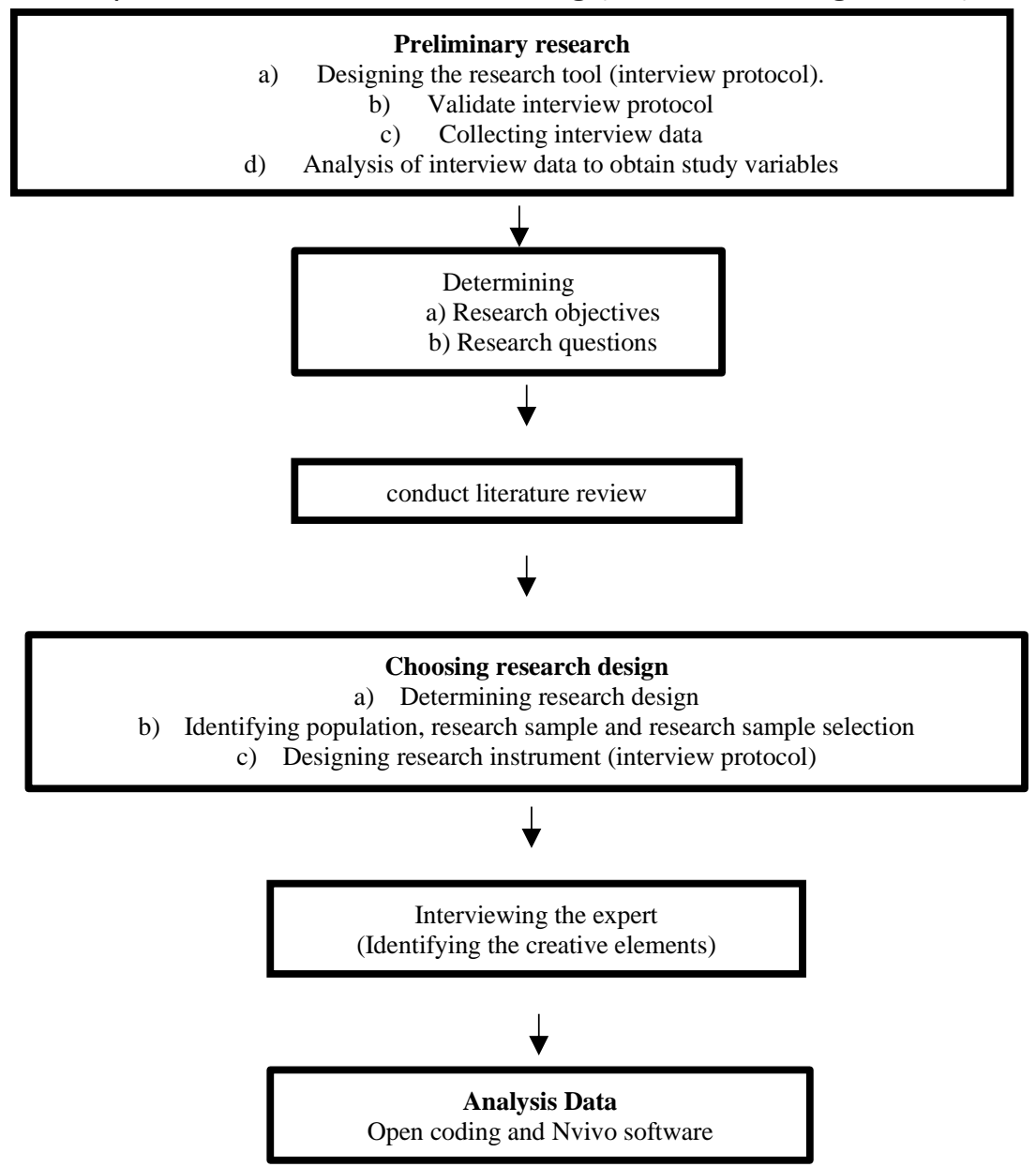

Figure 3.2: Research process 
Identifying the research problem is the main aspect when conducting a qualitative research design. It is identified by conducting an initial study and the result of the initial study is used to construct the research supported by the literature review. The initial research data was collected by interview based on a validated guideline. It is to explore the challenges faced by PVMA (automotive) teachers in conducting online based learning and how they overcome the challenges. The data were then analysed and use to formulate the research variables, research objectives and research questions.

\section{Population, Sample, Sample Size and Sampling Method of the Study}

Population refers to a group of individuals (humans, things or animals) which has the same characteristics (Creswell, 2015) while, the research sample refers to a specific group of the population (Shearer and Webster, 1985). Thus, in this research, the population refers to a total of 59 PVMA teachers throughout Malaysia and only 5 participants were selected as the research sample in this study due to the purposive sampling method.

\section{Result}

This section discusses the research through qualitative research method. The interview was analysed using open coding, axial coding and selective coding and Nvivo software. A total of 5 participants who are expert PVMA teachers were interviewed to help with the research questions. The interview ended when the research has achieved the data saturation point. The result from the interview has found that the creative elements shown by PVMA (automotive) teachers in the online teaching and learning process were based on the problems that they encounter during the online teaching and learning session. These creative elements match with the one proposed by Sternberg (2006). The creative elements mentioned can be found in table 4.1 as below: 
Table 4.1: Analysis of creative elements in online teaching and learning of PVMA (automotive) teacher

\begin{tabular}{|c|c|c|c|}
\hline Participant & $\begin{array}{c}\text { Topic } \\
\text { discussed }\end{array}$ & Dimension (creative element) & Construct \\
\hline P1 & $\begin{array}{l}\text { Online } \\
\text { teaching } \\
\text { method }\end{array}$ & $\begin{array}{l}\text { - } \text { Planning } \\
\text { - } \text { organizing } \\
\text { - } \text { able to make decision } \\
\text { - } \text { willingness to try different } \\
\text { method } \\
\text { - } \text { show the reality } \\
\text { - conduct research } \\
\text { - } \text { ability to use many teaching } \\
\text { techniques. }\end{array}$ & $\begin{array}{l}\text { - } \text { Teaching style } \\
\text { - } \text { Teaching style } \\
\text { - } \text { Personality } \\
\text { - } \text { Personality } \\
\text { - } \text { Teaching style } \\
\text { - } \\
\text { - Teaching style } \\
\text { - Teaching style }\end{array}$ \\
\hline $\mathrm{P} 2$ & $\begin{array}{l}\text { Online } \\
\text { teaching } \\
\text { method }\end{array}$ & $\begin{array}{l}\text { - } \text { Planning } \\
\text { - } \text { organizing } \\
\text { - } \text { ability to adapt based on real-life } \\
\text { situation } \\
\text { - } \text { cooperation } \\
\text { - } \\
\text { - } \\
\text { change teaching method }\end{array}$ & $\begin{array}{l}\text { - } \text { Teaching style } \\
\text { - } \text { Teaching style } \\
\text { - } \text { Teaching style } \\
\text { - } \text { environment } \\
\text { - } \text { cooperation } \\
\quad \text { Personality } \\
\text { - }\end{array}$ \\
\hline P3 & $\begin{array}{l}\text { Online } \\
\text { teaching } \\
\text { method }\end{array}$ & $\begin{array}{ll}\text { - } & \text { organizing } \\
\text { - } & \text { planning } \\
\text { - } & \text { ability to adapt based on real-life } \\
& \text { situation } \\
\text { - } & \text { creative } \\
\text { - } & \text { Discussion } \\
\end{array}$ & $\begin{array}{l}\text { - } \text { Teaching style } \\
\text { - } \text { Teaching style } \\
\text { - } \text { Teaching style } \\
\text { - } \quad \text { thinking } \\
\text { - } \quad \text { skills } \\
\text { cooperation }\end{array}$ \\
\hline P4 & $\begin{array}{l}\text { Online } \\
\text { teaching } \\
\text { method }\end{array}$ & $\begin{array}{ll}- & \text { organize } \\
\text { - } & \text { planning } \\
\text { - } & \text { strategy planning } \\
\end{array}$ & $\begin{array}{l}\text { - Teaching style } \\
\text { - } \text { Teaching style } \\
\text { - } \quad \text { Teaching style }\end{array}$ \\
\hline P5 & $\begin{array}{l}\text { Online } \\
\text { teaching } \\
\text { method }\end{array}$ & $\begin{array}{ll}\text { - } & \text { update plan } \\
\text { - } & \text { organize } \\
\text { - } & \text { Dare to make a decision } \\
\text { - } & \text { Dare to try } \\
\text { - } & \text { Based on the real situation } \\
\text { - } & \text { Diversifying teaching techniques }\end{array}$ & $\begin{array}{l}\text { - } \text { Teaching style } \\
\text { - } \text { Teaching style } \\
\text { - Personality } \\
\text { - Personality } \\
\text { - Environment } \\
\text { - } \text { Teaching style }\end{array}$ \\
\hline
\end{tabular}


Table 4.2 shows the method used by PVMA (automotive) teacher to conduct their online lesson.

\begin{tabular}{|c|c|c|}
\hline Participant & Methods applied & $\begin{array}{c}\text { Result from Open coding dan } \\
\text { Nvivo }\end{array}$ \\
\hline P1 & $\begin{array}{l}\text { Google meet, webinar video, handouts } \\
\text { (explanation and work procedure). } \\
\text { Combining technology and manual } \\
\text { method accordingly. }\end{array}$ & $\begin{array}{l}\text { Technology - google meet, video, } \\
\text { webinar } \\
\text { Manual- Handouts, training } \\
\text { materials. }\end{array}$ \\
\hline P2 & $\begin{array}{l}\text { Combining technology and manual } \\
\text { method using Google meet, webinar } \\
\text { video, video call, Telegram, WhatsApp, } \\
\text { handouts, toolbox and exercises. }\end{array}$ & $\begin{array}{l}\text { Technology - google meet, webinar, } \\
\text { video call, telegram, what apps } \\
\text { Manual- Handouts, training } \\
\text { materials, tool box }\end{array}$ \\
\hline P3 & $\begin{array}{l}\text { Prepare materials manually for } \\
\text { practical learning using toolbox } \\
\text { concept. Guidelines, explanations and } \\
\text { manuals sent via Google meet, } \\
\text { Telegram, WhatsApp. Pickup and } \\
\text { return done systematically done at } \\
\text { school. }\end{array}$ & $\begin{array}{l}\text { Technology- google meet What } \\
\text { Apps, telegram } \\
\text { Manual- tool box, return and } \\
\text { retrieval of training materials in } \\
\text { schools. }\end{array}$ \\
\hline P4 & $\begin{array}{l}\text { Explanations done through online } \\
\text { medium such as Google meet, webinar } \\
\text { and calling students who have } \\
\text { problems to access the internet. } \\
\text { Practical training done preparing the } \\
\text { materials needed manually. } \\
\text { Handouts for work procedure and tools } \\
\text { for practice were put at the guard } \\
\text { house. }\end{array}$ & $\begin{array}{l}\text { Technology - google meet, webinar } \\
\text { dan telephone } \\
\text { Manual- distribution of work } \\
\text { procedure sheets and tools for } \\
\text { practical training }\end{array}$ \\
\hline P5 & $\begin{array}{l}\text { Online learning through Google Meet, } \\
\text { Webinar video call, video recording on } \\
\text { theoretical explanation and work } \\
\text { procedure were prepared by teachers. } \\
\text { Materials needed for practical training } \\
\text { using a special box. Students will pick } \\
\text { up and return the materials at the } \\
\text { guard house. }\end{array}$ & $\begin{array}{l}\text { Technology - google meet, webinar } \\
\text { video call and video recording } \\
\text { Manual- training materials in a tool } \\
\text { box in the guard house }\end{array}$ \\
\hline
\end{tabular}

\section{Discussion}

The application of using both technology and physical manual highlight teachers' creativity to ensure an effective learning and help with students' understanding during the online learning session especially for technical education. The aim is to ensure that the teaching objectives can be achieved through students' evidence.

The problems or challenges faced by teachers have forced them to become creative in conduction lesson especially for PVMA (automotive) teachers. They utilize the online applications as well as traditional method by distributing learning materials manually to overcome the problems. Through the analysis of the interview, it can be said that the best 
DEVELOPMENT

Vol. 10, No. 3, 2021, E-ISSN: 2226-6348 @ 2021 HRMARS

practice for PVMA (automotive) teachers and other technical education teachers is to combine both online resources and traditional method to achieve an effective online lesson.

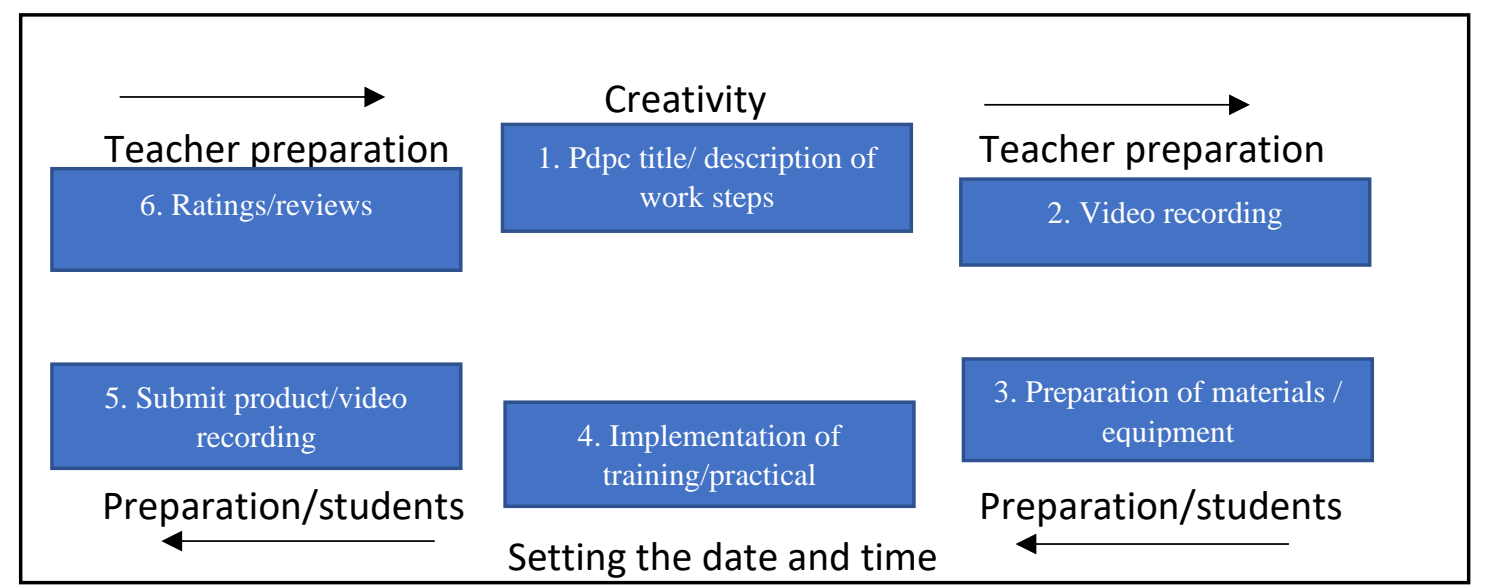

Figure 5.1: Steps in conduction lesson for PVMA automotive

Teachers become creative in conducting lessons when they are able to identify the problem and tools to be used to ensure an effective lesson in technical and vocational education especially the PVMA (automotive). Online learning coupled with traditional method distribute materials manually to students were used to overcome the challenges presented due to the pandemic. Through research, it was found that the most effective method in conducting teaching and learning process for technical and vocational education, specifically PVMA are as follow: Based on figure 5.1, these are the best teaching method used for PVMA (automotive) students:

a. The selection of topic and exercise depend entirely on the teachers' creativity.

b. Video recording by the teachers to be included in the lesson for the students.

c. Tools and materials in a box kid prepared by teachers will be collected by the students at school or other designated venue.

d. Exercises done by students according to the time and date set

e. Students submit their work

f. Evaluation and feedback by teachers using appropriate application.

\section{Conclusion}

In the effort of fighting Covid-19, the educational system has undergone a tremendous shift especially in the field of vocational education and training. The implementation of Movement Control Order (MCO) has forced the PVMA automotive teachers to find an alternative for students to ensure a continuous learning to the PVMA automotive students as they need to finish their vocational education and training within 2 years. Teachers become creative in utilizing technological applications such as Google Meet, video call, Telegram, WhatsApp as the main platform in online learning to complete the syllabus within the timeframe given. Meanwhile, the combination of manual teaching method such as distributing the standard operating procedure, tools and materials using the toolbox system become the main highlight of their creative teaching process.

There is no denial that a traditional face-to-face learning is more impactful than online learning however, the teachers' effort and creativity is commendable as they are able to ensure a continuous learning experience for students even during the pandemic. In planning 
for the lessons, teachers would have to consider several factors such as the content of the subject taught, learners, equipment, and facilities available before conducting their lesson and this is not an easy task as it involves higher order thinking skills.

This study is designed to increase the motivation of teachers and students to continue their learning session with the aid of technology. It is also hoped that this study could be of help for teachers to continue with their work despite environment-related challenges, facilities and students' interaction that is also present in the traditional face-to-face learning. To add, this study will also become teachers' resources in finding alternatives to conduct a lesson especially for technical subject. Last but not least, teachers and students could indirectly enhance their technological skills.

Future research in this field could:

1. Focus in one particular topic in the practical learning syllabus to decide the best teaching method.

2. The topic of this research could also be expanded by adding more technological elements in the learning session to provide a wider variety to the students.

3. Consideration in the preparation of the materials and equipment used should be taken into account for interested parties.

4. Encouragement and support from the school administrative by providing an appropriate token of appreciation is needed for the teachers and student to increase their motivation level.

5. The research scope should be expanded for other technical subjects as well.

It is hoped that future studies could present beneficial findings that could be utilized by teachers and educators from all around the world.

\section{Reference}

Abdul Latip. (2020). The Role of Information and Communication Technology Literacy in Distance Learning in the Covid-19 Pandemic. Edu Teach: Journal of Education and Learning Technology, Volume 1, No. 2 June 2020 Edition

Adiguzel, O. C., \& Cardak, C. S. (2009). An Evaluation of the "Computer Technology and Programming" Curriculum in the Vocational Higher Education System in Turkey. Journal of Industrial Teacher Education, 45, 61-83. Retrieved from http://search.ebscohost.com/login.aspx?direct=true \&db=eft\&AN=508118861\&site=e host-live

Alsafi, Z., Abbas, A. R., Hassan, A., \& Ali, M. A. (2020). The coronavirus (COVID-19) pandemic: Adaptations in medical education. International Journal of Surgery, 78, 64-65.

Area-Moreira, M., bethencourt-Aguilar, A., Martín-Gómez, S. (2020) from blended teaching to online teaching in the days of Covid19. Student visions (Review). Universidad de La Laguna, Spain

Barron F., \& Harrington, D. M. (1981). Creativity Intelligence and Personality. Department of Psychology, University of California

Chin, C. (2020). Teaching through the telly. Sunday Star: 1

Cohen, J., Manion, L., dan Morrison, K. (2007). Research Methods in Education. (8th ed.). London:Routledge Falmer. 
DEVELOPMENT

Vol. 10, No. 3, 2021, E-ISSN: 2226-6348 @ 2021 HRMARS

Creswell, J. W. (2014). Research design Qualitative, Quantitative, and Mixed Methods Approaches, E-book Fourth Edition. SAGE Publication Los Angeles

Creswell, J. W., \& Clark, V. L. P. (2007) Designing and Conducting Mixed Methods Research. Book reviews. School of Public Health, La Trobe University, Victoria.

Creswell, J. W. (2015). Educational Research Planning, Conducting and Evaluating Quantitative and Qualitative Research. Book 5th ed. SAGE Publication Los Angeles.

Currie, G., Hewis, J., Nelson, T., Chandler, A., Nabasenja, C., Spuur, K., ... Kilgour, A. (2020). COVID-19 impact on undergraduate teaching: Medical radiation science teaching team experience. Journal of Medical Imaging and Radiation Sciences, 51(4), 518-527.

Deepika, A., Kandakatla, R., Saida, A., \& Reddy, V. B. (2021). Implementation of ICAP principles through technology tools: Exploring the alignment between pedagogy and technology. Journal of Engineering Education Transformations, 34(Special Issue), 542-549.

Dua, A. B., Kilian, A., Grainger, R., Fantus, S. A., Wallace, Z. S., Buttgereit, F., \& Jonas, B. L. (2020). Challenges, collaboration, and innovation in rheumatology education during the COVID-19 pandemic: leveraging new ways to teach. Clinical Rheumatology, 39(12), 3535-3541. https://doi.org/10.1007/s10067-020-05449-x

Duta, N., Panisoara, G., \& Panisoara, I.-O. (2015). The Effective Communication in Teaching. Diagnostic Study Regarding the Academic Learning Motivation to Students. Procedia Social and Behavioral Sciences, 186, 1007-1012.

https://doi.org/10.1016/j.sbspro.2015.04.064

Hibbi, F. Z., Abdoun, O., \& Khatir, H. E. I. (2020). Coronavirus pandemic in Morocco: Measuring the impact of containment and improving the learning process in higher education. International Journal of Information and Education Technology, 11(1), 30-34. https://doi.org/10.18178/ijiet.2021.11.1.1485

Kaplan, B., \& Maxwell, J. A. (2005). Qualitative Research Methods for Evaluating Computer Information Systems. Sage Publication. USA.

Khairy J. (2021). https://www.sinarharian.com.my/article/133283/KHAS/ Covid-19/Fasakedua-program-imunisasi-diteruskan-seperti-dirancang-Khairy

Kumar, A., Malhotra, S., Katoch, A., Sarathkar, A., \& Manocha, A. (2020). Webinars: An assistive tool used by higher education educators during Covid19 case study. Proceedings - 2020 12th International Conference on Computational Intelligence and Communication Networks, CICN 2020, 327-332.

Linacre, J. M. (2005). Optimizing Rating Scale Category Effectiveness. Journal of Applied Measurement, 3(1), 85-106.

Maier V., Alexa L., Craciunescu R. (2020). Online education during the COVID19 pandemic: Perceptions and expectations of romanian students. European Conference on eLearning

Mehta, R., Henriksen, D., \& Rosenberg, J. M. (2019). It's not about the tools. Educational Leadership, 76(5), 64-69.

Mishra, P., \& Mehta, R. (2017). What we educators get wrong about 21st-century learning: Results of a sur- vey. Journal of Digital Learning in Teacher Education, 33(1), 6-19.

Mohammadian, H. D., Shahhoseini, H. S., Castro, M., \& Merk, R. (2020). Digital Transformation in Academic Society and Innovative Ecosystems in the World beyond Covid19-Pandemic with Using 7PS Model for loT. Proceedings of 2020 IEEE Learning With MOOCS, LWMOOCS 2020, 112-117. https://doi.org/10.1109/LWMOOCS50143.2020.9234328 
Nuere, S., \& de Miguel, L. (2020). The Digital/Technological Connection with COVID-19: An Unprecedented Challenge in University Teaching. Technology, Knowledge and Learning, (0123456789). https://doi.org/10.1007/s10758-020-09454-6

Kadir, M. N. A., \& Ismail, S. (2021). Creativity Practice in Teaching and Facilitating (PDPC) Malaysia's PVMA Automotive Due Covid-19 Pandemic. International Journal of Academic Research in Progressive Education and Development, 10(3), 410-425.

Reilly, R. C., Lilly, F., Bramwell, G., \& Kronish, N. (2011). A synthesis of research concerning creative teachers in a Canadian context. Teaching and Teacher Education, 27(3), 533542

Rinkevich, J. L. (2011). Creative Teaching: Why it Matters and Where to Begin Creative Teaching: Why it Matters. The Clearing House: A Journal of Educational Strategies, Issues and Ideas, 84(5), 219-223

Shearer, C. A., \& Webster, J. (1985), Aquatic hyphomycete communities in the River Teign. III. Comparison of sampling techniques Elsevier Ltd Published.

Singer, R. N. (1980). Motor Learning and Human Performance an Application to Motor Skills and Movement Behaviors. New York: MacMillan Publishing Co., Inc.

Sternberg, R. J. (2006). The Nature of Creativity. Creativity Research Journal. 18(1): 87-98.

Syed, K., Kandakatla, R., Madhulita, Yadav, R. I., \& Himasagarika, R. (2021). Responding to COVID-19 and transitioning to online learning: Evaluation of an institution wide capacity building efforts on technology-enhanced learning. Journal of Engineering Education Transformations, 34(Special Issue), 620-627. https://doi.org/10.16920/jeet/2021/v34i0/157232

Worlitz, J., Stabler, A., Peplowsky, S. \& Woll, R. (2016). Video Tutorials: An Appropriate Way of Teaching Quality Management Tools Applied with Software. Quality Innovation Proseperity. 20(2):169-184 